ISSN (Print) : 1412-7601

ISSN (Online) : 2654-8712

Volume 5, No.2 September 2019

http://www.ekonobis.unram.ac.id

EKONOBIS

\title{
Dinamika Kependudukan Dan Dampaknya Terhadap Perubahan Lingkungan (Kasus Penambangan Batu Apung Ijobalit Kec. Labuan Haji Lombok Timur)
}

\author{
Jalaluddin, Irwan Suriadi
}

Universitas Mataram

ARTICLE INFO

Keywords :

Population dynamics, Indepth Interview and Focus Group Discussion (FGD), East Lombok Hajj Labuhan
ABSTRACT : This study aims to determine the impact of population dynamics on environmental changes that occur in ljobalit Village, Labuhan Haji District, East Lombok. This research used a qualitative approach by applying several data collection methods, namely Observation, Indepth Interview, and Focus Group Discussion (FGD). The data analysis was carried out in a qualitative descriptive manner based on field information. Some important conclusions from this study are: 1) Pumice mining emerged as an implication of the high population growth which was not followed by an increase in the quality of human resources (HR) and the provision of adequate employment. This condition triggers pressure on the surrounding environment to become the most possible source of livelihood because it does not require special skills. 2). Pumice mining activities in ljobalit Village, Labuhan Haji District, East Lombok Regency are generally classified as community mining, wherein the operations only traditional equipment that been used, even manually. 3). Ijobalit pumice mining activities use an open-pit mining system by peeling the topsoil layer which has an impact on reducing the level of fertility and damage to soil structure, causing the soil is easily eroded.

Kata Kunci :

Dinamika kependudukan, Indepth Interview dan Focus Group Discussion (FGD), Labuhan haji Lombok Timur

\section{ABSTRAK: Kajian ini bertujuan untuk mengetahui dampak dari dinamika kependudukan} yang terjadi terhadap perubahan lingkungan yang terjadi di Kelurahan ljobalit Kecamatan Labuhan Haji Lombok Timur. Metode atau pendekatan penelitian yang digunakan adalah pendekatan kualitatif dengan menerapkan beberapa metode pengambilan data yaitu Observasi/Pengamatan, Indepth Interview dan Focus Group Discussion (FGD). Sementara analisis data dilakukan secara dekriftif kualitatif berdasarkan informasi lapangan. Beberapa kesimpulan penting dari kajian ini adalah : 1)Penambangan batu apung muncul sebagai implikasi dari tingginya pertumbuhan penduduk yang tidak diikuti dengan peningkatan kualitas sumberdaya manusia (SDM) dan penyediaan lapangan pekerjaan yang cukup. Kondisi ini memicu tekanan terhadap lingkungan sekitar untuk dijadikan sumber penghidupan yang paling memungkinkan karena tidak membutuhkan keterampilan khusus. 2). kegiatan penambangan batu apung di Kelurahan ljobalit Kecamatan Labuhan Haji Kabupaten Lombok Timur secara umum tergolong penambangan rakyat dimana dalam kegiatan operasinya hanya menggunakan peralatan tradisional, bahkan dilakukan secara manual. 3). kegiatan penambangan batu apung ljobalit menggunakan sistem penambangan terbuka (open pit mining) dengan mengupas lapisan top soil (tanah penutup) yang berdampak pada penurunan tingkat kesuburan dan kerusakan struktur tanah sehingga menyebabkan tanah mudah mengalami erosi.

Corresponding Author :

Alamat : Program Studi Ekonomi Pembangunan, Fakultas Ekonomi dan Bisnis, Universitas Mataram, Jln. Majapahit No. 62 Mataram.

e-mail: Jalaluddin@unram.ac.id 


\section{PENDAHULUAN}

Latar Belakang

Pelaksanaan pembangunan seutuhnya menempatkan manusia sebagai titik sentral dalam pembangunan. Dalam kerangka ini, pembangunan ditujukan untuk memajukan kesejahteraan umum, mencerdaskan kehidupan bangsa dan meningkatkan partisipasi rakyat dalam semua proses dan kegiatan pembangunan. Dengan demikian, pembangunan manusia sejatinya menjadi tujuan utama pembangunan melalui peningkatan kemampuan sumber daya manusia, agar mampu sebagai subyek pembangunan.

Sensus penduduk tahun 2010 mencatat pertumbuhan penduduk Indonesia melebihi proyeksi nasional yaitu sebesar 237,6 juta jiwa dengan laju pertumbuhan penduduk (LPP) 1,49 per tahun. Dengan laju pertumbuhan penduduk sebesar itu, maka maka setiap tahun penduduk Indonesia akan bertambah sebanyak kurang lebih sekitar 3,5 juta orang.Ini berarti bahwa penduduk Indonesia tahun 2020 diperkirakan akan berjumlah 271,1 juta jiwa dan 305,6 juta pada tahun 2035, sekaligus menempatkan Indonesia menjadi negara dengan jumlah penduduk terbesar ke 4 (empat) di dunia setelah Cina India dan Amerika Serikat .
Jumlah penduduk yang besar bisa menjadi potensi yang besar pula dalam proses pembangunan, karena sesungguhnya penduduk merupakan pelaku, sasaran dan sekaligus sebagai penikmat hasil pembangunan. Hal ini bisa terjadi jika jumlah penduduk yang besar dengan komposisi dan distribusi yang lebih merata disertai dengan kualitas yang baik dan memadai akan menjadi pendorong kemajuan pembangunan. Namun hal ini juga dapat menjadi beban dalam proses pembangunan apabila kualitasnya rendah. Penduduk dengan kualitas rendah akan menjadi hambatan dalam meraih peluang dan kesempatan yang ada. Bahkan, beberapa persoalan lingkungan yang muncul selama ini diyakini sebagai implikasi dari dinamika kependudukan semacam ini.

Masalah lingkungan bukanlah sesuatu yang berdiri sendiri, melainkan sangat erat hubungannya dengan masalah kependudukan dalam konteks penduduk dan pembangunan. Dalam hal ini, kerusakan lingkungan tidak hanya sebagai akibat dari bertambahnya penduduk serta meningkatnya kebutuhan hidup manusia (Mantra, 2000). Aktivitas lain yang saling memberikan benang merah terhadap kerusakan lingkungan adalah 
pertambahan penduduk, walaupun bukanlah satu-satunya penyebab rusaknya lingkungan.

Pada tahun 1991, tercatat manusia yang memerlukan lahan (tanah), air dan udara di bumi ini untuk hidup telah mencapai jumlah 5,2 miliar. Jumlah manusia penghuni planet bumi pada tahun 1998 berjumlah 6,8 miliar, dan pada tahun 2000 mencapai 7 miliar. Kalau pertumbuhan penduduk tetap dipertahankan seperti sekarang, menurut Paul R. Ehrlich, 900 tahun lagi (tahun 2900) akan ada satu biliun orang di atas planet bumi ini atau 1700 orang permeter persegi. Kalau jumlah ini diteruskan sampai 2000 atau 3000 tahun kemudian, berati jumlah orang yang ada sudah melebihi berat bumi itu sendiri.

Laju pertumbuhan penduduk Indonesia menurut Sensus Penduduk 2010 melebihi program dan proyeksi nasional yaitu sebesar 237,6 juta jiwa dengan laju pertumbuhan penduduk (LPP) 1,49\% per tahun. Dengan laju pertumbuhan sebesar ini maka setiap tahun akan terjadi pertambahan penduduk sekitar 3,5 juta lebih. Bila laju pertumbuhan tidak ditekan atau dicegah maka jumlah penduduk Indonesia pada 2045 akan mencapai 450 juta jiwa, hal ini berarti satu dari 20 penduduk dunia adalah orang Indonesia.
Apabila pertumbuhan penduduk terus bertambah, sementara laju pertumbuhan ekonomi berjalan lamban, maka kemiskinan makin bertambah dan akan mempengaruhi kehidupan sosial lainnya serta berdampak pada eksistensi lingkungan.

Pertumbuhan penduduk yang relatif tingggi, berimplikasi pada kondisi biofisik lingkungan, permasalahan ekonomi, kesenjangan sosial dan ketersediaan lahan yang cukup untuk menopang kesejahteraan hidup manusia. Sementara lahan yang tersedia bersifat tetap dan tidak bertambah sehingga menambah beban lingkungan. Daya dukung alam ternyata makin tidak seimbang dengan laju tuntutan pemenuhan kebutuhan hidup penduduk. Aktivitas seperti eksplorasi dan eksploitasi sistematis terhadap sumber daya alam dan lingkungan yang dilakukan secara terus menerus untuk memenuhi kebutuhan ekonomi dan sosial semakin memperberat daya dukung lingkungan yang pada gilirannya akan merusak ekosistem lingkungan itu sendiri.

\section{Rumusan Masalah}

Jumlah penduduk yang terus bertambah menyebabkan kepadatan populasi juga mengalami peningkatan, yang pada gilirannya akan berpengaruh terhadap 
daya dukung lingkungan. Daya dukung lingkungan yang terbatas menyebabkan terjadinya kelangkaan sumber daya alam, terjadinya pencemaran, dan timbul persaingan untuk mendapatkan sumber daya alam. Selain itu pertumbuhan penduduk yang tinggi tanpa diikuti pertumbuhan ekonomi yang memadai sering kali hanya menghasilkan sumber daya manusia yang berkualitas rendah. Masalah kependudukan dan kerusakan lingkungan hidup merupakan dua permasalahan yang kini sedang dihadapi bangsa Indonesia, khususnya maupun negara-negara lainnya di dunia umumnya. Masalah lingkungan hidup dan kependudukan seperti masalah pencemaran lingkungan fisik, desertifikasi, deforestasi, overs eksploitasi terhadap sumber-sumber alam, serta berbagai fenomena degradasi ekologis semakin hari semakin menujukkan peningkatan yang signifikan. Keprihatinan ini tidak saja memberikan agenda penanganan masalah lingkungan yang bijak. Namun juga merupakan "warning" bagi kehidupan, bahwa kondisi lingkungan hidup sedang berada pada tahap memprihatinkan. Seandainya tidak dilakukan upaya penanggulangan secara serius, maka dalam jangka waktu tertentu kehidupan ini akan musnah (Brown 1992). Hal ini terjadi karena lingkungan (alam) tidak mampu lagi memberikan apa-apa kepada kita. Padahal seperti kita ketahui bahwa manusia merupakan bagian integral dari lingkungan hidupnya, ia tidak dapat dipisahkan dari padanya.

Jauh sebelum Brown mengungkapkan keperihatinannya, sekitar dua abad yang laluThomas Robert Maltus seorang sosiolog Inggris, mengemukakan teori yang berjudul Essay on The Principle of Population. Maltus menyimpulkan bahwa pertambahan penduduk mengikuti deret ukur, sedangkan pertambahan produksi pangan mengikuti deret hitung. Lebih dari itu, menurut Maltus, permasalahan kependudukan dan lingkungan hidupseperti kekeringan, banjir, bahaya kelaparan, wabah penyakit, yang disebut positive checks, terjadi sebagai akibat ketidak-seimbangan pertambahan jumlah penduduk dan lingkungan alam. Malthus yakin bahwa manusia akan tetap hidup miskin/melarat dan berakhir dengan kematian, selama terjadi ketidakseimbangan jumlah penduduk dengan daya dukung lingkungan, khususnya ketidak-seimbangan jumlah penduduk dengan persediaan bahan makanan.

Apa yang menjadi keperihatinan Brown maupun Maltus sekitar dua abad yang lalu ternyata telah terbukti kebenarannya. 
Kerusakan lingkungan akibat ketidakseimbangan penduduk dan daya dukung lahan terjadi dimana-mana termasuk di Kabupaten Lombok Timur khususnya di Kelurahan ljobalit Kecamatan Labuhan Haji yang menjadi lokasi penelitian ini. Lokasi ini merupakan sentra penambangan bahan galian $\mathrm{C}$ khususnya penambangan Batu Apung terbesar di Lombok Timur, bahkan di pulau Lombok. Akibat dari eksploitasi lingkungan ini tentu telah membawa dampak terhadap perubahan ataupun kerusakan lingkungan. Untuk mengetahui sejauh mana perubahan dan atau kerusakan lingkungan yang terjadi sebagai akibat eksploitasi lingkungan yang terjadi di Kelurahan ljo Balit, inilah yang menjadi alasan mengapa penelitian ini penting untuk dilakukan.

\section{Tujuan Penelitian}

Secara umum kajian ini bertujuan untuk mengetahui dampak dari dinamika kependudukan yang terjadi terhadap perubahan lingkungan yang terjadi di Kelurahan ljobalit Kecamatan Labuhan Haji Lombok Timur. Sedangkan secara khusus penelitian ini bertujuan untuk :

1. Mengidentifikasi jenis-jenis perubahan dan atau kerusakan lingkungan yang terjadi akibat eksploitasi lingkungan yang terjadi di Kelurahan ljobalit Kecamatan Labuhan Haji Lombok Timur

2. Mengetahui solusi yang dibutuhkan dalam mengatasi persoalan kerusakan lingkungan yang terjadi.

3. Memberikan rekomendasi kepada pemerintah dan pihak terkait terhadap persoalan lingkungan yang terjadi hususnya di Kelurahan Ijo Balit kecamatan Labuhan Haji Lombok Timur.

\section{TINJAUAN PUSTAKA}

Penduduk dan Pembangunan

Penduduk merupakan unsur penting dalam usaha untuk meningkatkan produksi dan mengembangkan kegiatan ekonomi. Penduduk memegang peranan penting karena menyediakan tenaga kerja, tenaga ahli, tenaga usahawan yang diperlukan untuk menciptakan kegiatan ekonomi. Di samping itu, pertambahan jumlah penduduk mengakibatkan bertambah dan makin kompleksnya kebutuhan (Yakin, 1997). Pertumbuhan penduduk suatu daerah dipengaruhi oleh fertilitas, mortalitas dan migrasi. Apabila angka fertilitas lebih besar daripada angka mortalitas, maka pertumbuhan penduduk menjadi positif. Begitu juga dengan migrasi, apabila nilai migrasi masuk lebih besar daripada nilai migrasi keluar, maka 
pertumbuhan penduduk menjadi positif (Utina dan Baderan, 2013).

Peningkatan jumlah penduduk akan menyebabkan terjadinya pengangguran, meningkatnya penggunaan sumber daya alam, peningkatan standar hidup akan meningkatkan lebih tinggi lagi kebutuhan sumber daya alam baik yang dapat diperbaharui maupun yang tidak dapat diperbaharui. Makin banyak penghasilan, manusia akan semakin banyak membeli, menggunakan dan membuang sumber daya alam (Soerjani dkk, 1987). Jumlah penduduk yang terus meningkat serta belum tertibnya pelaksanaan tata guna lahan menyebabkan tekanan terhadap pemanfaat lahan makin besar. Kompetisi diantara berbagai kepentingan terhadap lahan makin ketat. Atas nama pembangunan seringkali (lahan) pertanian yang menjadi korban atau dikorbankan (Utina dan Baderan, 2013).

Pemahaman yang berbeda terhadap perubahan penduduk serta faktor-faktor yang terkait dengannya memiliki pengaruh yang berbeda juga kepada kebijakan pemerintah yang berlaku. Berdasarkan sejarah kependudukan, terdapat dua pandangan terhadap perubahan penduduk ini. Pandangan pertama menyatakan pembangunan mempengaruhi dinamika penduduk, artinya penduduk berfungsi sebagai dependent variabel. Pandangan kedua menyatakan kondisi kependudukan akan mempengaruhi pembangunan yang dilaksanakan. Dalam hal ini penduduk menjadi independent variabel (Hardiani dan Junaidi, 2011).

Malthus merupakan orang pertama yang memberikan gambaran secara sistematis mengenai hubungan antara penyebab dan akibat-akibat pertumbuhan penduduk melalui karya-karya fenomenalnya. Buku Malthus pertama adalah "Essay on the Principle of Population as it affects the future improvement of society; With remarks on the speculations of Mr.Godwin, M.Condorcet, and other writer" yang dipublikasikan tahun 1798. Pada tahun 1803 buku tersebut direvisi dengan judul "An Essay on the Principle of Population; or a view of its past and present effects on human happiness; with an inquiry into our prospects respecting the future removal of mitigation of the evils which it occasions". (Lucas, et.al 1990). Dalam model dasarnya, Malthus menggambarkan suatu konsep tentang pertambahan hasil yang semakin berkurang (diminishing returns). Malthus menyatakan bahwa umumnya penduduk suatu negara mempunyai kecenderungan untuk bertambah menurut suatu deret 
ukur $(1,2,4,8,16,32)$. Kecenderungan ini menyebabkan penduduk akan berlipat ganda setiap 30-40 tahun, kecuali bila terjadi bahaya kelaparan. Pada saat yang sama, karena adanya pertambahan hasil yang semakin berkurang dari suatu faktor produksi yang jumlahnya tetap (tanah dan sumberdaya alam lainnya) maka persediaan pangan hanya akan meningkat menurut deret hitung $(1,2,3,4,5,6,7)$.

Menurut Malthus, karena setiap anggota masyarakat hanya memiliki tanah yang sedikit, maka kontribusi marginal atau produksi pangan akan semakin menurun.

Pada masyarakat agraris, pendapatan perkapita dapat diartikan sebagai produksi pangan perkapita. Oleh karenanya, ketika pertumbuhan pangan tidak dapat mengimbangi pertambahan penduduk yang pesat, maka pendapatan perkapita akan mengalami penurunan. Penurunan pendapatan perkapita ini akan menjadi sedemikian rendahnya sehingga mencapai sedikit di atas tingkat subsisten (kemiskinan absolut). Gagasan Malthus mengenai penduduk yang terpaksa hidup pada tingkat pendapatan subsisten ini diistilahkan oleh para ekonom modern sebagai "jebakan kependudukan dengan tingkat ekuilibrium yang rendah" (low level-equilibrium population trap) atau sering disingkat dengan "jebakan kependudukan Malthus" (Malthusian population trap).

Malthus menyatakan bahwa sebagaimana tumbuh-tumbuhan dan hewan, manusia sebagai makhluk memiliki insting yang sangat kuat untuk menambah jumlah populasinya. Oleh karenanya, jika pertumbuhan penduduk tidak dikontrol, jumlah manusia akan berlipat ganda dalam jumlah tak terbatas. Malthus juga mengemukakan bahwa usaha untuk menghambat laju pertumbuhan penduduk dapat dilakukan melalui dua cara. Pertama, adalah melalui positive check. Positive check adalah semua hal yang memberikan kontribusi terhadap penurunan kehidupan manusia, yang berdampak pada berkurangnya jumlah penduduk. Sebagai contoh adalah kemiskinan, wabah penyakit, perang, kelaparan dan lainnya. Kedua, adalah melalui preventive check. Dalam teorinya, preventive check mencakup semua cara yang memungkinkan untuk mengontrol kelahiran, termasuk abstinensi, kontrasepsi dan aborsi. Namun demikian, Malthus hanya menerima cara pencegahan kelahiran melalui moral restrain", dalam bentuk menunda perkawinan, sampai pada waktu dimana orang tersebut yakin bahwa keluarga yang dibentuknya tidak terjebak pada 
kemiskinan yang berdampak pada penurunan kualitas hidup masyarakat. Cara pencegahan kelahiran yang lain, termasuk kontrasepsi (baik sebelum atau dalam perkawinan), aborsi, pembunuhan bayi atau cara-cara yang tidak patut lainnya, dipandang sebagai perbuatan jahat yang dapat menurunkan martabat manusia. Menurut Malthus, moral restraint merupakan hal yang paling penting, karena dia percaya bahwa mengizinkan pencegahan kelahiran melalui cara-cara yang tidak patut tersebut (prostitusi, kontrasepsi, aborsi atau sterilisasi), akan menghamburhamburkan energi dengan cara yang tidak produktif secara ekonomi.

Malthus menyatakan bahwa akibat utama dari pertumbuhan penduduk adalah kemiskinan. Hal ini didasarkan atas argumennya bahwa (1) manusia mempunyai kecenderungan alami untuk mempunyai anak (2) pertumbuhan bahan makanan tidak dapat menyamai pertumbuhan penduduk. Dalam analisisnya, Malthus cenderung sependapat dengan Adam Smith. Selain kebutuhan tenaga kerja (demand for labor) sebagai penyebab pertumbuhan penduduk, sebagaimana yang dikemukakan oleh Adam Smith, Malthus percaya bahwa dorongan untuk ber- reproduksi merupakan faktor yang mendahului sebelum kebutuhan tenaga kerja. Secara implisit ini mengisyaratkan bahwa over-population (yang diukur dengan tingkat pengangguran) akan menekan upah menjadi turun sampai titik dimana penduduk tidak sanggup untuk menikah dan membentuk keluarga.

\section{Penduduk dan Lingkungan Hidup}

Lingkungan terdiri atas komponen biotik (hidup) dan abiotik (tak hidup). Jika komponen biotik berada dalam komposisi yang proporsional antara tingkat trofik dengan komponen abiotik yang mendukung kehidupan komponen biotik, lingkungan tersebut berada dalam keseimbangan atau stabil. Menurut Undang-Undang No. 32 Tahun 2009 tentang Perlindungan dan Pengelolaan Lingkungan Hidup, Lingkungan hidup adalah kesatuan ruang dengan semua benda, daya, keadaan, dan makhluk hidup, termasuk manusia dan perilakunya, yang mempengaruhi alam itu sendiri, kelangsungan perikehidupan, dan kesejahteraan manusia serta makhluk hidup lain (Utina dan Baderan, 2013).

Daya dukung lingkungan menurut Odum (1971) merupakan jumlah populasi organisme yang kehidupannya dapat didukung oleh suatu kawasan atau ekosistem. Definisi Daya dukung 
lingkungan hidup adalah kemampuan lingkungan hidup untuk mendukung perikehidupan manusia, makhluk hidup lain, dan keseimbangan antar keduanya. Daya dukung lingkungan atau carrying capacity, meliputi; (1) Jumlah organisme atau spesies khusus secara maksimum dan seimbang yang dapat didukung oleh suatu lingkungan, (2) Jumlah penduduk maksimum yang dapat didukung oleh suatu lingkungan tanpa merusak lingkungan tersebut, (3) Jumlah makhluk hidup yang dapat bertahan pada suatu lingkungan dalam periode jangka panjang tanpa membahayakan lingkungan tersebut, (4) Jumlah populasi maksimum dari organisme khusus yang dapat didukung oleh suatu lingkungan tanpa merusak lingkungan tersebut, (5) Ratarata kepadatan suatu populasi atau ukuran populasi dari suatu kelompok manusia di bawah angka yang diperkirakan akan meningkat, dan di atas angka yang diperkirakan untuk menurun yang disebabkan oleh kekurangan sumber daya, (6) Kapasitas pembawa akan berbeda untuk tiap kelompok manusia dalam sebuah lingkungan tempat tinggal disebabkan oleh jenis makanan, tempat tinggal, dan kondisi sosial dari masingmasing lingkungan tempat tinggal tersebut.
Pelestarian daya dukung lingkungan hidup adalah rangkaian upaya untuk melindungi kemampuan lingkungan hidup terhadap tekanan perubahan dan/atau dampak negatif yang ditimbulkan oleh suatu kegiatan agar tetap mampu mendukung perikehidupan manusia dan makhluk hidup lain. Menurut Caughley (1979) sebagaimana disitasi Utina dan Baderan (2013), daya dukung dibagi menjadi dua tipe, yaitu daya dukung ekologi dan daya dukung ekonomi. Daya dukung ekologi menjelaskan ukuran herbivora dan populasi tanaman yang dapat dicapai secara alami apabila keduanya dibiarkan berinteraksi tanpa ada intervensi manusia. Sementara itu, daya dukung ekonomi menjelaskan suatu kesetimbangan yang ditimbulkan oleh kelestarian pemanenan populasi herbivora.

Pertumbuhan populasi manusia telah mengakibatkan perubahan yang besar dalam lingkungan hidup. Permasalahan lingkungan hidup menjadi besar karena kemajuan teknologi. Akan tetapi yang harus diingat bahwa teknologi bukan saja dapat merusak lingkungan, melainkan diperlukan juga untuk mengatasi masalah lingkungan hidup. Pertumbuhan populasi manusia menyebabkan timbulnya permasalahan lingkungan, seperti: 
kerusakan hutan, pencemaran, erosi, dan lain-lain karena manusia selalu berinteraksi (inter-related) dengan makhluk hidup lainnya dan benda mati dalam lingkungan. Ini dilakukan manusia untuk dapat memenuhi kebutuhan hidupnya dalam upaya mempertahankan jenis dan keturunannya (Utina dan Baderan, 2013).

Pemenuhan kebutuhan manusia dapat terpenuhi karena adanya pemanfaatan lingkungan yang berbentuk pengelolaan lingkungan hidup. Melalui pengelolaan lingkungan hidup, terjadi hubungan timbal balik antara lingkungan biofisik dengan lingkungan sosial. Ini berarti sudah berkaitan dengan konsep ekologi, terutama tentang konsep hubungan timbal balik (inter-related) antara lingkungan biofisik dengan lingkungan sosial. Dengan demikian apabila membicarakan lingkungan hidup, maka konsep ekologi akan selalu terkait sehingga permasalahan lingkungan hidup adalah permasalahan ekologi (Utina dan Baderan, 2013).

\section{METODE PENELITIAN}

Penelitian ini sepenuhnya menganalisis data dan informasi dari lapangan langsung (data primer) yang didukung atau diperkuat oleh data-data dari pihak lainnya (data sekunder). Metode penelitian atau pendekatan yang digunakan adalah pendekatan kualitatif deskriftif dengan menerapkan beberapa metode pengambilan data yakni : (i). Observasi/Pengamatan, tujuannya adalah untuk mendapatkan gambaran tentang kondisi umum wilayah penelitian (social setting, physical setting dll) melalui dokumentasi foto/gambar; (ii). Indepth Interview dengan sejumlah key informan yang dipilih secara purposive berdasarkan kebutuhan penelitian; (iii). Focus Group Discussion (Kelompok Diskusi Terfokus) dengan peserta 8-10 orang selama 1 kali kegiatan. Partisipannya berasal dari keluarga/RT yang dipilih secara purposive sesuai dengan karakteristik lokasi penelitian. Untuk mendukung analisa terhadap data-data primer, kajian ini juga dilengkapi dengan desk study berupa review terhadap data dan informasi sekunder baik berupa laporan-laporan sebelumnya (laporan penelitian, laporan program) maupun data statistik (Monografi Desa, Kabupaten Dalam Angka, Kecamatan Dalam Angka).

Sasaran dari kegiatan penelitian ini adalah informan kunci maupun para partisipan mewakili unsur-unsur : indepth interview (SKPD bidang Kependudukan di Kabupaten; Kepala Desa; Kepala Dusun; Tokoh Masyarakat, LSM dan 
Keluarga/Rumah Tangga); FGD (RT/Keluarga penambang bahan galian golongan $\mathrm{C})$;

\section{HASIL DAN PEMBAHASAN}

Pembangunan berpusat pada penduduk (People centered development)

Dinamika kependudukan dan lingkungan hidup memiliki keterkaitan erat satu sama lain. Perubahan parameter kependudukan (jumlah, komposisi, struktur umur dan pertumbuhan) akan berdampak pada berbagai aspek lingkungan hidup baik lingkungan alam maupun buatan. Sebaliknya, perubahan lingkungan hidup akan mempengaruhi aspek kependudukan (BKKBN, 2002). Tekanan terhadap lingkungan dapat terjadi jika tingginya tingkat pertumbuhan penduduk tidak disertai dengan peningkatan kualitasnya ditambah lagi dengan faktor-faktor lain seperti pola konsumsi dan perkembangan teknologi.

Berbagai permasalahan akan muncul ketika tekanan tersebut telah melampui daya dukung dan daya tampung lingkungan. Padatnya penduduk perdesaan mendorong pergerakan orangorang dari desa ke kota sehingga akan bermuara pada munculnya sejumlah persoalan kependudukan di perkotaan seperti : pengangguran, kemiskinan, pemukiman liar, kawasan kumuh dan tumpukan sampah. Di tataran global, tekanan penduduk akan meningkatkan beban pembangunan menghadapi perubahan lingkungan akibat pencemaran dan maraknya konversi lahan hingga pada giliran dapat memicu kerawanan pangan. Khusus wilayah perdesaan, peningkatan kuantitas dan laju perkembangan penduduk berimplikasi pada 3 (tiga) hal yakni : penggunaan lahan dan konversi lahan; kepadatan penduduk agraris; dan peluang kerja di luar sektor pertanian.

Peningkatan penggunaan lahan dan konversi lahan. Meningkatnya kuantitas penduduk dan terjadinya transformasi dari masyarakat agraris pedesaan menuju masyarakat industri perkotaan mendorong terjadinya konversi lahan untuk tujuan perkembangan pertanian dan modernisasi. Intervensi terhadap kawasan hutan menjadi tidak terelakkan lagi untuk dibuka menjadi lahan-lahan perkebunan dan pertanian. Sementara, kawasan pertanian produktif lainnya berubah fungsi menjadi daerah perdagangan dan industri serta tempat tinggal. Peningkatan jumlah penduduk menjadikan konversi lahan menjadi pilihan yang paling memungkinkan di tengah makin meningkatnya kebutuhan hidup. Diperkirakan luasan lahan 
produktif yang akan dikonversi mencapai 700 ribu hektar dalam 25 tahun ke depan. Kepadatan penduduk agraris. Kepadatan penduduk agraris ditentukan oleh jumlah penduduk yang kehidupannya tergantung pada pertanian (penduduk petani) dan luas lahan pertanian yang terdapat di suatu wilayah. Ketika bidang pertanian tidak mungkin lagi menyerap tenaga kerja yang terus meningkat akibat dari tingginya tekanan penduduk di sektor pertanian, maka kesempatan kerja di luar sektor pertanian menjadi sangat penting untuk menampung mereka. Beberapa faktor penyebab terjadinya kondisi ini terjadi, antara lain : (1) sempitnya kepemilikan lahan sawah per setiap rumah tangga petani (RTP); (2) upah riil yang rendah di sektor pertanian dan pekerjaan-pekerjaan pertanian tidak tersedia secara kontinyu (hanya musiman); dan (3) adanya peluang untuk berusaha di sektor non-pertanian yang semakin terbuka.

Peluang kerja di luar pertanian. Jumlah penduduk petani berubah dari waktu ke waktu karena terjadinya perkembangan kuantitas penduduk suatu daerah dan faktor-faktor yang menyebabkan terjadinya perkembangan kuantitas penduduk suatu daerah dan faktor-faktor yang menyebabkan terjadinya pergeseran mata pencaharian dari sektor pertanian ke sektor non-pertanian (industri dan jasa) sebagai bagian dari transformasi masyarakat tradisional menuju masyarakat industri modern. Pergeseran ini berangsur-angsur akan mempengaruhi jumlah penduduk petani di suatu wilayah. Di saat peluang usaha di bidang pertanian tidak mampu menyerap tenaga kerja yang terus meningkat, penciptaan peluang usaha di sektor non-pertanian sangat dibutuhkan bagi mereka yang terdorong ke luar dari sektor pertanian.

Perspektif pembangunan berkelanjutan menjadi basis pemikiran bagi penetapan kebijakan atau langkah strategis untuk menyelesaikan persoalan klasik terkait kependudukan dan daya dukung lingkungan. BKKBN (2017) memaknai pembangunan berkelanjutan sebagai suatu proses pembangunan yang mengoptimalkan manfaat sumber daya alam dan sumber daya manusia secara berkelanjutan, dengan cara menyerasikan aktivitas manusia sesuai dengan kemampuan sumber alam yang menopangnya dalam suatu ruang wilayah daratan, lautan, dan udara sebagai satu kesatuan. Dengan demikian, pembangunan berkelanjutan tidak bisa dilepaskan dengan pemanfaatan ruang wilayah beserta potensi sumber daya yang ada bagi tujuan pembangunan manusia 
atau masyarakatnya itu sendiri. Agenda utama pembangunan berkelanjutan adalah upaya untuk memadukan, mengintegrasikan, dan memberi bobot yang sama bagi tiga pilar utama pembangunan, yaitu ekonomi, sosialbudaya, dan lingkungan hidup. Penduduk merupakan titik sentral dalam proses pembangunan berkelanjutan karena penduduk merupakan pelaku sekaligus penerima manfaat pembangunan. Konsep ini diterjemahkan lebih lanjut dalam konsep "pembangunan berwawasan kependudukan".

Pembangunan

berwawasan

kependudukan merupakan pendekatan pembangunan terpusat pada penduduk (people-centered development) yang menekankan keharusan perencanaan memperhatikan kondisi dan dinamika kependudukan atau 'population responsive'. Data dan informasi kependudukan secara lengkap harus diperhatikan dan dipertimbangkan mulai dari jumlah, pertumbuhan, struktur umur, persebaran maupun kualitas penduduk. Di sisi lain, pemerintah juga harus mampu merumuskan kebijakan pengelolaan kependudukan agar tercapai kondisi kependudukan yang kita harapkan (population-influencing policies). Secara sederhana pembangunan berwawasan kependudukan menurut Utina dan Baderan (2013) mengandung 2 (dua) makna yaitu : pertama, pembangunan yang disesuaikan dengan potensi dan kondisi penduduk yang ada. Penduduk menjadi objek dan subjek yang harus dilibatkan secara langsung dalam proses pembangunan; kedua, pembangunan yang menitik beratkan kemampuan atau skill sumberdaya manusia, dimana Pembangunan lebih menekankan pada peningkatan kualitas sumberdaya manusia dibandingkan dengan pembangunan infrastruktur semata.

\section{Dinamika Kependudukan Lombok Timur}

Jumlah dan Pertumbuhan Penduduk

Kabupaten Lombok Timur memiliki jumlah penduduk terbesar dari semua kabupaten yang ada di provinsi Nusa Tenggara Barat (NTB) dan jumlahnya mengalami peningkatan pesat dari satu periode ke periode lainnya baik berdasarkan hasil Sensus Penduduk (SP) maupun metode registrasi penduduk lainnya. Pada tahun 1961, jumlah penduduk tercatat 494.168 jiwa dan mengalami peningkatan sekitar 20,5 persen hingga menjadi 595.527 jiwa di tahun 1970. Pada tahun 2017, jumlah penduduk Lombok Timur telah mencapai 1.208.594 jiwa dengan komposisi $47: 53$ antara laki-laki (563.179 jiwa) dan perempuan (645.512 jiwa). 
Laju pertumbuhan penduduk Lombok Timur cenderung menurun dalam kurun waktu lima puluh tahun terakhir. Pola pertumbuhan ini diyakini merupakan kecenderungan demografi sebagai dampak dari pelaksanaan program pemerintah seperti : KB dan transmigrasi.
Selain itu, faktor penyebab lainnya adalah mobilisasi penduduk karena berbagai alasan dan pengaruh perilaku hubungan sosial. Rata-rata laju pertumbuhan penduduk Lombok Timur menurut data sensus disajikan pada gambar 1 . berikut ini

Gambar 1.

Laju Pertumbuhan Penduduk Lombok Timur berdasarkan data Sensus Penduduk (persen)

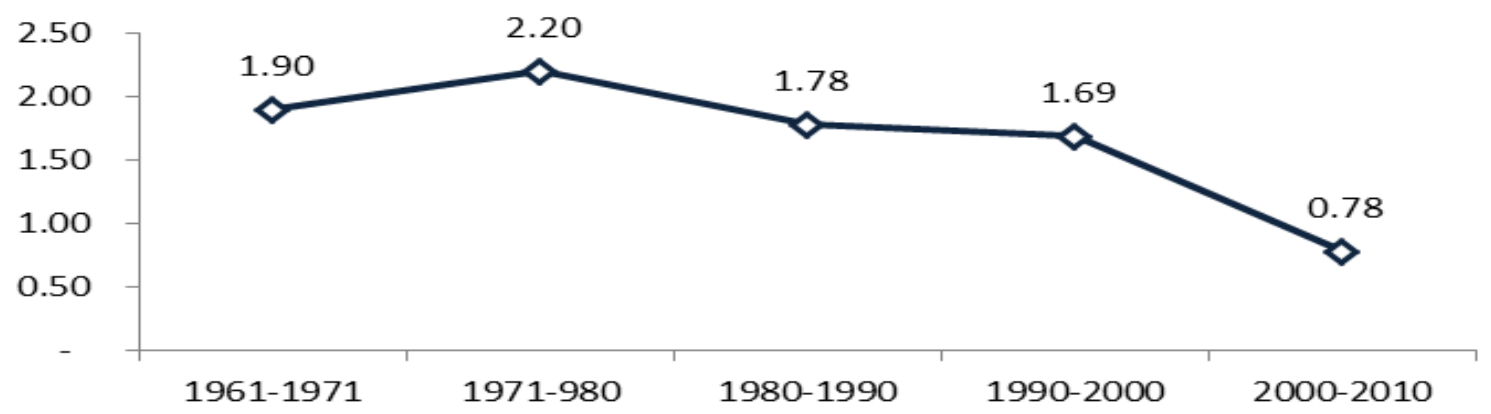

Dari grafik tersebut dapat dilihat bahwa laju pertumbuhan penduduk tertinggi terjadi pada periode tahun 1971-1980 karena faktor tingginya tingkat kelahiran. Sementara, periode-periode berikutnya pertumbuhan penduduk mulai dapat ditekan seiring dengan berkurangnya jumlah penduduk secara signifikan. Penurunan angka kelahiran diyakini sebagai salah satu faktor penyebab kondisi ini karena semakin banyaknya pasangan usia subur mulai menggunakan alat kontrasepsi (alat KB) untuk membatasi jumlah kelahiran dan mengatur jarak kelahiran.
Selain itu, kecenderungan penurunan jumlah penduduk juga disebabkan oleh adanya kesadaran untuk penundaan usia perkawinan pertama dan program transmigrasi ke luar pulau (terutama Sulawesi dan Kalimantan). Berikut data penggunaan akseptor KB (aktif dan baru) sebagai salah satu indikasi penurunan jumlah penduduk periode 2000-2010.

\section{Persebaran dan Kepadatan Penduduk}

Perbedaan sumber daya antara satu wilayah dengan wilayah lainnya menjadi salah satu faktor yang mengakibatkan terjadinya perbedaan sebaran penduduk. Biasanya penduduk akan mengumpul pada suatu wilayah yang dapat 
menunjang kehidupannya. Selain itu, persebaran penduduk juga di pengaruhi pula oleh kebijakan kependudukan yang digariskan oleh Pemerintah Daerah dalam rencana tata ruang Lombok Timur.

Penyebaran penduduk Lombok Timur paling banyak terdapat di Kecamatan Masbagik, diikuti oleh Aikmel, Pringgabaya dan Selong. Konsentrasi penduduk pada 4 (empat) wilayah ini bisa terjadi mengingat roda kegiatan ekonomi pada kecamatan-kecamatan tersebut cukup aktif karena merupakan jalur lalu lintas distribusi dan perdagangan komoditas pertanian di Lombok Timur sehingga memungkinkan tersedianya sumber penghidupan bagi penduduk. Berikut distribusi penduduk Lombok Timur menurut Data BPS 2014.

Gambar 2

Distribusi Penduduk Lombok Timur per Kecamatan, 2017

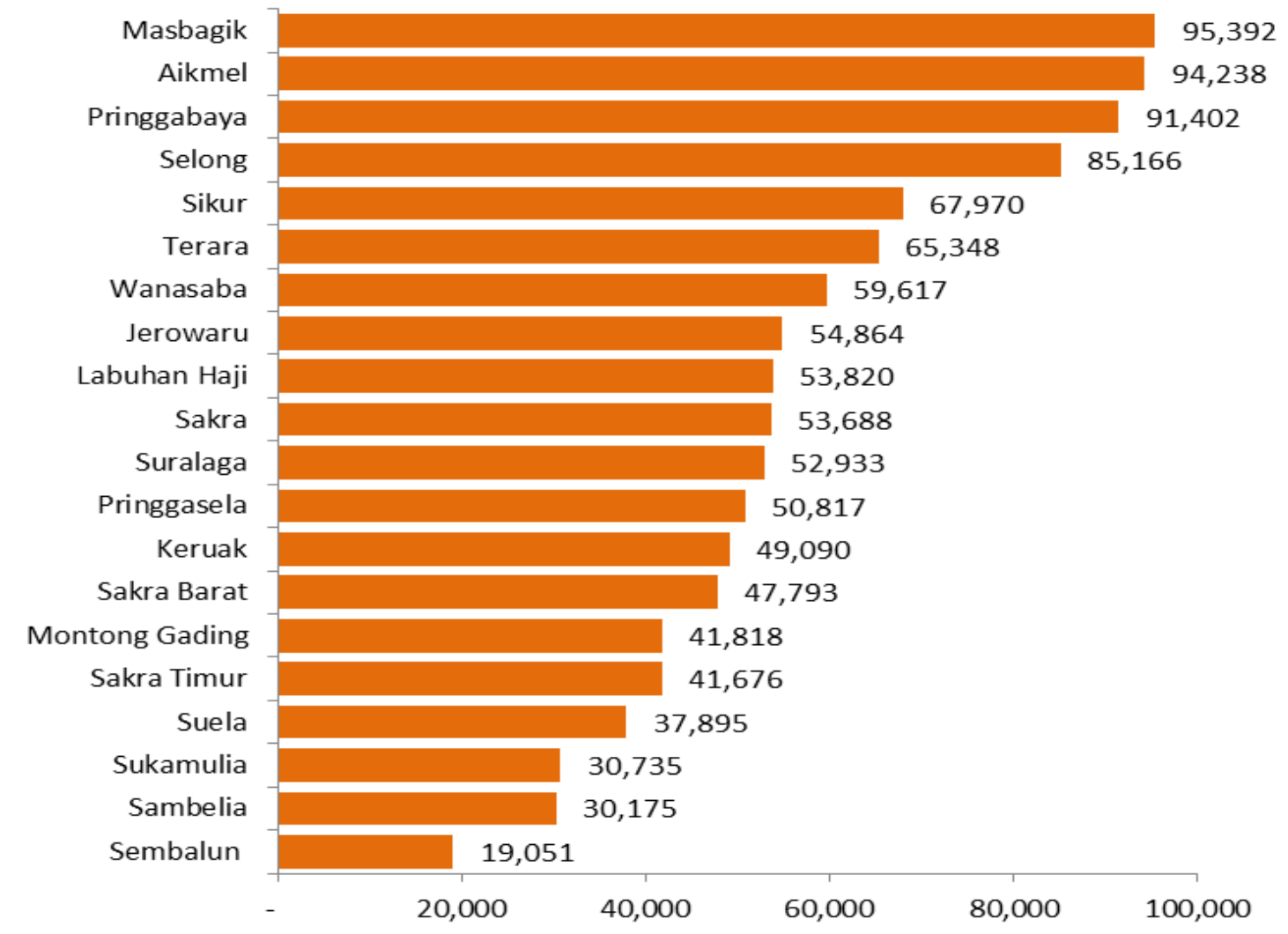

Konsentrasi penduduk 'sedang' pada kecamatan-kecamatan lainnya disebabkan karena wilayahnya hasil dari pemekaran sehingga ada distribusi penduduk dengan kecamatan induk sebelumnya (Wanasaba,
Suralaga, Pringgasela, Montong Gading, Jerowaru, Suela, Sakra Barat, Sakra Timur). Sementara, kecamatan dengan penduduk relatif 'sedikit' (Sembalun, Sambelia dan Swela) merupakan wilayah kawasan dan sekitar areal hutan Gunung 
Rinjani. Kecamatan-kecamatan ini termasuk kawasan penyangga (buffer zone) bagi kehidupan sebagian besar penduduk di Pulau Lombok dan memiliki posisi strategis sebagai area resapan air (catchment area) bagi pemenuhan kebutuhan wilayah lainnya.

\section{Struktur Penduduk}

Struktur penduduk dapat ditinjau menurut jenis kelamin maupun umur. Kajian struktur penduduk sangat penting bagi pengambil keputusan dalam merencanakan pembangunan berbagai fasilitas pelayanan penduduk, terutama yang berkaitan dengan pelayanan umum, seperti fasilitas kesehatan, pendidikan dan fasilitas sosial lainnya.

Rasio jenis kelamin (RJK) adalah perbandingan antara banyaknya penduduk laki-laki terhadap penduduk perempuan. Angka RJK yang lebih tinggi dari 100 menunjukkan bahwa jumlah penduduk laki-laki lebih besar dibandingkan dengan jumlah penduduk perempuan. Angka sex ratio penduduk di Lombok Timur di bawah 100 (laki-laki terhadap perempuan) yang berarti bahwa jumlah penduduk perempuan lebih besar daripada laki-laki. Pada tahun 2013, angka sex ratio penduduknya mencapai 87,09 (setiap seratus penduduk penduduk perempuan, terdapat 87 orang penduduk laki - laki). Dari segi umur, struktur penduduk Lombok Timur (BPS, 2013) didominasi oleh penduduk muda (young population), sebagaimana disajikan dalam gambar 3.

Gambar 3

Struktur Penduduk Lombok Timur

Berdasarkan Usia dan Jenis Kelamin, 2017.

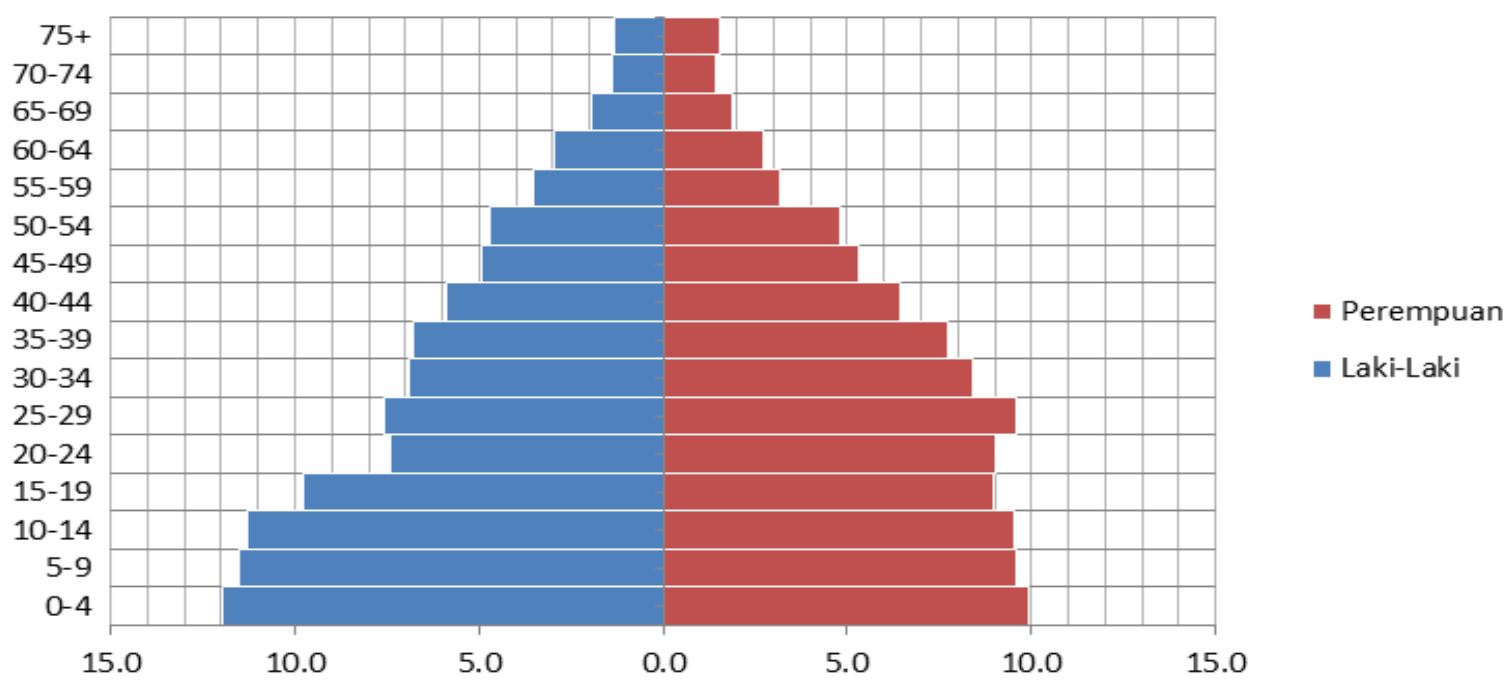


Berdasarkan gambar tersebut, tampak bahwa dasar piramida semakin membesar yang berarti proporsi penduduk anakanak (0-14 tahun) selama periode 10 tahun terakhir semakin banyak. Sebaliknya penduduk usia produktif (1564 tahun) dan usia lanjut semakin mengecil. Pergeseran jumlah penduduk menurut kelompok umur ini akan berimplikasi pada perubahan kebijakan ekonomi dan sosial berdasarkan perspektif kependudukan. Misalnya, semakin banyaknya jumlah penduduk usia anak-anak berarti kebutuhan sarana pendidikan dasar semakin bertambah sehingga diharapkan sumber daya yang ada dapat dimanfaatkan untuk meningkatkan kualitas pendidikan. Demikian juga dengan masalah kesehatan, intervensi pemerintah dapat lebih ditekankan pada segi kualitas, seperti pemberian imunisasi, peningkatan kualitas pelayanan kesehatan, promosi gerakan hidup sehat dan sebagainya.

Jumlah penduduk usia produktif meskipun menunjukkan indikasi semakin berkurang, namun hal ini harus diantisipasi oleh pembuat kebijakan terutama yang bersangkut paut dengan pendidikan dan tenaga kerja. Karena bisa jadi penduduk berusia anak-anak pada tahun 2010, tetapi pada tahun 2013 sudah memasuki usia produktif. Implikasinya, kesempatan mengenyam pendidikan lanjutan harus diperluas dengan menyediakan sarana pendidikan yang dapat dijangkau oleh semua lapisan masyarakat. Selain itu pendidikan harus mampu merangsang siswa untuk mengembangkan potensi dirinya sehingga mampu untuk mandiri dan bekerja sesuai dengan bidang yang diminati.

Dalam bidang ketenagakerjaan, pembuat kebijakan harus menyediakan dan memperluas lapangan pekerjaan guna mengurangi missmatch antara lapangan pekerjaan dengan pendidikan. Jika penduduk usia produktif tidak tertampung di sekolah atau lapangan kerja maka mereka berpotensi untuk menimbulkan masalah sosial yang akan meresahkan masyarakat. Meskipun proporsi penduduk lansia paling kecil dibandingkan kelompok penduduk anak-anak dan produktif namun peningkatan jumlah penduduk usia lansia (65 tahun ke atas) harus mendapat perhatian dari pemerintah. Misalnya, penyediaan sarana dan prasarana penunjang segala kebutuhan mereka dari hal pelayanan kesehatan, penyediaan sarana penampungan atau panti jompo dan penyantunan bagi yang tidak mampu. 


\section{Fertilitas}

Fertilitas adalah istilah yang umum digunakan untuk mengindikasikan banyaknya anak yang lahir hidup sehingga menjadi ukuran kemampuan reproduksi wanita. Tingkat Fertilitas dapat diukur dengan Angka Kelahiran Kasar (Crude Birth Rate $=(B R)$, Angka Fertilitas Umum (General Fertility Rate $=$ GFR), Angka Fertilitas Total $($ Total Fertility Rate $=$ TFR), Rasio Anak-Ibu (Child Woman Ratio = CWR), dan Paritas/Jumlah Anak Yang dilahirkan Hidup/ALH (Children Ever Born $=(\mathrm{CEB})$. CBR merupakan angka sangat kasar karena mengukur banyaknya kelahiran untuk setiap 1.000 penduduk dengan membagi banyaknya kelahiran dengan penduduk secara keseluruhan yang mencakup penduduk anak-anak, dewasa dan lansia dengan tidak membedakan jenis kelamin.

GFR mengukur banyaknya kelahiran per 1.000 wanita usia subur (15-49 tahun) pada pertengahan tahun. Ukuran ini lebih baik daripada CBR karena hanya mempertimbangkan penduduk wanita usia subur (15-49 tahun). Tetapi angka ini juga kurang spesifik karena tidak membedakan resiko melahirkan dari berbagai kelompok umur. Artinya kelahiran yang berasal dari ibu yang berusia 15-19 tahun diperlakukan sama dengan jumlah kelahiran dari ibu yang berusia lebih tua. Ukuran yang paling baik adalah TFR. TFR adalah rata-rata jumlah anak yang akan dilahirkan oleh seorang wanita selama masa reproduksinya, menurut kelompok umurnya pada tahun yang bersangkutan. Angka ini lebih spesifik karena memperhatikan jumlah kelahiran menurut kelompok umur wanita dengan interval 5 tahunan, yaitu dari usia (15-19) tahun hingga kelompok usia (4449) tahun.

Ukuran-ukuran sebagaimana dijelaskan sebelumnya tidak dapat dihitung dan disajikan dalam laporan ini karena keterbatasan data yang tersedia. Secara statistik, data tersedia hanya memuat informasi tentang jumlah kelahiran bayi yang dilaporkan pada tahun 2013 sesuai dengan wilayah kerja 29 puskesmas yakni 25.749. Dari jumlah tersebut, sebanyak 25.547 (99.2 \%) dilaporkan lahir hidup.

\section{Mortalitas}

Kematian atau mortalitas merupakan komponen demografi penentu dinamika kependudukan selain fertilitas dan migrasi. Bila fertilitas berhubungan dengan penambahan penduduk, maka mortalitas merupakan pengurangan dari penduduk. Tingkat kematian yang terjadi umumnya berbeda menurut golongan umur, jenis kelamin maupun keadaan 
sosial ekonomi penduduk. Dengan demikian tingkat kematian yang terjadi di suatu wilayah seringkali dihubungkan dengan tingkat kemajuan sosial ekonomi wilayah tersebut.

Semakin baik kondisi sosial ekonomi suatu wilayah ditunjang dengan semakin lengkapnya sarana dan prasarana kesehatan, maka akan semakin baiknya derajat kesehatan masyarakat. Implikasinya angka kesakitan (morbidity rate) dan angka kematian (mortality rate) dapat diperkecil. Indikator kematian yang sering digunakan adalah Angka Kematian Kasar (Crude Death Rate $=$ CDR), Angka Kematian Menurut Kelompok Umur (Age Specific Death Rate $=$ ASDR) dan Angka Kematian Bayi (Infant Mortality Rate = IMR).

Angka Infant Mortality Rate (IMR) yaitu perbandingan antara jumlah kematian bayi di bawah usia 1 tahun selama tahun tertentu terhadap jumlah kelahiran selama tahun tersebut dikali dengan 1.000. Angka kematian bayi berbanding terbalik dengan angka harapan hidup (e0), karena bayi yang rentan terhadap penyakit mempunyai resiko kematian tinggi sulit untuk diharapkan mempunyai umur yang panjang. Angka Harapan Hidup dan IMR dapat dijadikan ukuran derajat kesehatan suatu wilayah.
Tidak semua indikator mortalitas dapat ditampilkan secara detail dalam laporan ini karena ketersediaan data yang terbatas. Berdasarkan rilis BPS (2017), AHH Kabupaten Lombok sekitar 61,90 tahun atau lebih rendah dari rata-rata AHH NTB (63,21 tahun). Data BPS (2017) mencatat 202 kasus lahir mati dan 591 bayi mati.

\section{Migrasi}

Migrasi merupakan salah satu komponen peubah penduduk baik sifatnya menambah atau mengurangi jumlahnya melalui perpindahan dengan tujuan untuk menetap dari suatu tempat/wilayah ke tempat/wilayah lainnya yang melampaui batas administratif. Faktor utama penyebab terjadinya perpindahan penduduk meliputi faktor pendorong (push factor) dari daerah asal dan faktor penarik (pull factor) dari daerah tujuan. Faktor-faktor pendorong perpindahan penduduk, meliputi : kurangnya sumber daya alam yang tersedia di daerah asal, sempitnya lapangan pekerjaan, terjadinya bencana alam dan sebagainya. Sedangkan, faktor penarik di daerah tujuan adalah pesatnya pembangunan di segala bidang, tersedianya lapangan pekerjaan yang cukup luas, keadaan sosial ekonomi masyarakat yang mapan dan lainnya. 
Penduduk Lombok Timur umumnya melakukan mobilisasi ke luar wilayah untuk tujuan transmigrasi maupun bekerja menjadi TKI ke luar negeri guna mencari penghidupan lebih baik. Pada tahun 2013, peserta transmigrasi hanya 19 KK dengan 76 jiwa ke kabupaten baik dalam lingkup NTB (Pulau Sumbawa) atau daerah luar NTB (Sulawesi, Kalimantan, Papua dII). Sementara, aktifitas pengiriman TKI ke luar negeri terus meningkat sejalan dengan masih tingginya animo masyarakat bekerja di luar negeri. Pada tahun 2017, sebanyak 19.885 orang TKI diberangkatkan ke sejumlah negara tujuan atau meningkat dua kali lipat dibandingkan tahun sebelumnya yakni 9.917 orang.

\section{Kondisi Lingkungan Hidup}

\section{Kerusakan Sumberdaya Hutan}

Pertumbuhan, perkembangan dan penyebaran penduduk di suatu wilayah telah membawa dampak positif dan negatif terhadap lingkungan hidup. Dampak positif yang dirasakan oleh manusia, antara lain berupa peningkatan kemakmuran serta kesejahteraan sebagai dampak dari pengolahan dan pemanfaatan sumber daya lingkungan. Sedangkan dampak negatif berupa perusakan lingkungan seperti erosi, kekeringan, pencemaran, tanah longsor, banjir dan lain sebagainya. Masalah lingkungan ini patut mendapat perhatian. Karena jika pembangunan yang kita laksanakan mengabaikan faktor lingkungan, maka kerugian material maupun spiritual akan menimpa kehidupan masyarakat.

Kabupaten Lombok Timur adalah salah satu kabupaten yang berbatasan langsung dengan Taman Nasional Gunung Rinjani (TNGR). dari 50.106 hektar luas hutannya, 22.146 hektar (44,20\%) diantaranya adalah wilayah Taman Nasional Gunung Rinjani. Selebihnya adalah Hutan Lindung seluas seluas 20.841 hektar $(41,59 \%)$ dan Hutan Produksi hanya seluas 7.119 hektar $(14,21 \%)$. Dibandingkan dengan luas hutan di kabupaten lain dari total luas hutan di NTB (1.060.547,78 Ha) maka luas hutan di Kabupaten Lombok Timur menempati urutan kedua terkecil setelah Kabupaten Lombok Tengah.

Akibat kegiatan perambahan dan penebangan kayu hutan, kawasan hutan Lombok Timur mengalami degradasi yang cukup serius, sehingga lahan dalam kawasan hutan berubah menjadi lahan kritis. Data Sumberdaya Alam Spasial daerah Propinsi NTB yang memerinci data lahan kritis menurut pembagian DAS perkabupaten, mencantumkan data jumlah lahan kritis di Kabupaten Lombok Timur 
sampai akhir 2003 seluas 14.537,45 hektar, dimana dari angka tersebut $6.499,25$ hektar diantaranya yang ada dalam wilayah DAS Menanga, terutama sekitar 5.976,00 hektar berada dalam kawasan hutan dan sisanya $(523,25$ hektar) di luar kawasan hutan. Keadaan ini diperberat tekanan penduduk yang cukup besar, dimana dalam DAS Menanga bermukim penduduk berjumlah 584.757 jiwa yang berarti tingkat kepadatannya mencapai 577,25 jiwa/km2.

Aktifitas penebangan di wilayah tangkapan air (catchment area), mata air, hutan cagar alam maupun daerah konservasi lainnya mengakibatkan tingginya penguapan yang pada akhirnya berpengaruh pada hilangnya beberapa mata air atau paling tidak menurunkan debit air. SWS Menanga mengalami penurunan debit air rata-rata $63,40 \%$ hanya dalam kurun waktu 3 tahun. Penurunan secara keseluruhan juga sangat dirasakan oleh pengguna air di wilayah hilir di Kabupaten Lombok Timur baik pemakai air untuk kegiatan pertanian dan sektor domestik seperti rumah tangga dan pelanggan PDAM. Dengan melihat skala penurunan debit mata air yang cukup besar tersebut $(63,40 \%)$ dapat dikatakan telah terjadi proses degradasi dan deforestasi yang meluas di wilayah hulu terutama kawasan hutan yang berfungsi sebagai sabuk hijau (green belt) Gunung Rinjani.

Berdasarkan issue dan permasalahan pembangunan kehutanan dan pedesaan yang terjadi, maka pengembangan kawasan memerlukan alternatif solusi untuk pengembangan wilayah pedesaan. Konsep pengembangan kawasan, tidak semata-mata ditujukan kepada pembangunan fisik material tetapi juga sekaligus harus dikaitkan dengan pembangunan masyarakat/sumberdaya manusia secara langsung. Titik berat pembangunan masyarakat, khususnya masyarakat setempat memerlukan pendekatan yang bersifat integral dan terpadu, artinya pembangunan yang akan dilaksanakan tidak hanya menyangkut pembangunan struktur fisik atau lingkungan, tetapi sekaligus pembangunan manusia/masyarakat dengan pendekatan yang berimbang.. Pengembangan kawasan harus mempunyai keterkaitan yang harmonis antara pendekatan bottom up dengan kebijakan pembangunan kehutanan, yang bertujuan untuk mencapai multi-plyer effect.

Pengelolaan sumberdaya hutan secara terpadu menghendaki adanya keberlanjutan (sustainability) dalam 
pemanfaatan sumberdaya hutan. Sebagai kawasan yang dimanfaatkan untuk berbagai sektor pembangunan, hutan memiliki kompleksitas isu, permasalahan, peluang dan tantangan. Pemanfaatan sumberdaya hutan yang tidak memenuhi kaidah-kaidah pembangunan yang berkelanjutan secara signifikan mempengaruhi ekosistemnya. Kegiatan pembangunan yang ada di kawasan ini akan dapat mempengaruhi produktivitas sumberdaya akibat proses produksi dan residu, dimana pemanfaatan yang berbeda kerap menimbulkan konflik yang dapat berdampak timbal balik. Oleh karena itu pemanfaatan sumberdaya hutan untuk tujuan pembangunan akan dapat berhasil jika dikelola secara terpadu.

Pengelolaan sumberdaya hutan secara terpadu adalah suatu proses iterative dan evolusioner untuk mewujudkan pembangunan kawasan hutan secara optimal dan berkelanjutan. Tujuan akhir dari program ini bukan hanya untuk mengejar pertumbuhan ekonomi (economic growth) jangka pendek, melainkan juga menjamin pertumbuhan ekonomi yang dapat dinikmati secara adil dan proporsional oleh segenap pihak yang terlibat (stakeholders), dan memelihara daya dukung serta kualitas lingkungan, sehingga pembangunan dapat berlangsung secara lestari.

Dalam rangka mencapai tujuan tersebut maka unsur esensial adalah keterpaduan (integration) dan koordinasi. Setiap kebijakan dan strategi dalam pemanfaatan sumberdaya hutan harus berdasarkan kepada : (1) pemahaman yang baik tentang proses-proses alamiah (ekosistem) yang berlangsung di kawasan hutan yang sedang dikelola; (2) kondisi ekonomi, sosial, budaya dan politik masyarakat; dan (3) kebutuhan saat ini dan yang akan datang terhadap barang dan (produk) dan jasa lingkungan. Di dalam proses pengelolaan dilakukan identifikasi dan analisis mengenai berbagai isu pengelolaan atau pemanfaatan yang ada maupun yang diperkirakan akan muncul dan kemudian menyusun serta melaksanakan kebijakan dan program aksi untuk mengatasi isu yang berkembang.

Upaya mewujudkan pembangunan kawasan hutan secara berkelanjutan memerlukan keterpaduan dalam perencanaan dan pengelolaan kawasan pada empat aspek, yaitu : (a) keterpaduan wilayah/ekologis; (b) keterpaduan sektor; (c) keterpaduan disiplin ilmu; dan (d) keterpaduan stakeholder. Dengan kata lain, penetapan komposisi dan laju/tingkat 
kegiatan pembangunan kehutanan yang optimal akan menghasilkan pertumbuhan ekonomi yang dapat dirasakan oleh segenap stakeholders secara adil dan berkelanjutan. Pengelolaan wilayah hutan secara terpadu pada dasarnya merupakan suatu proses yang bersifat siklikal. Dengan demikian terlihat bahwa pendekatan keterpaduan pengelolaan/pemanfaatan kawasan pesisir dan laut menjadi sangat penting, sehingga diharapkan dapat terwujud one plan dan one management serta tercapai pembangunan yang berkelanjutan dan kesejahteraan masyarakat secara keseluruhan.

Deforestasi selain menyebabkan hutan rusak dan luasnya berkurang, juga dapat menyebabkan terjadinya perubahan bentuk hutan menjadi lahan kritis sehingga fungsi ekosistem hutan sebagai wilayah tangkapan air hujan, penyimpan dan penyalur menjadi terganggu. Terdapat sekitar 5.400 ha lahan kritis di Lombok Timur, bahkan 1.500 hektar berada di Kawasan Taman Nasional Gunung Rinjani (TNGR) sementara 600 hektar lainnya berada di Kawasan Sambelia yang terkena banjir Bandang. Dampak lain deforestasi, berupa tingginya erosi dan sedimentasi sehingga terjadi pendangkalan dan penyempitan badan sungai sehingga kondisi ini membuat tingkat kerentanan banjir dan longsor di sekitar DAS semakin tinggi.

Kejadian banjir bandang di sekitar di Wilayah Sembalun dan Sambelia baru baru ini memunculkan banyak pernyataan spekulasi mengenai faktor penyebabnya, apalagi kedua wilayah ini merupakan bagian dari zone kawasan hutan Gunung Rinjani yang selama ini dikenal sebagai kawasan penyangga (buffer zone) kehidupan sebagian besar penduduk di Pulau Lombok. Sebenarnya dari beberapa kajian yang dilakukan, bencana banjir yang terjadi di daerah - daerah rawan (termasuk kawasan hulu) pada dasarnya disebabkan oleh 3 (tiga) hal, yakni : pertama, aktifitas manusia yang menyebabkan terjadinya tata ruang dan berdampak pada perubahan alam; kedua, peristiwa alam seperti curah hujan yang sangat tinggi, kenaikan permukaan air laut, badai dan sebagainya; ketiga, degradasi lingkungan akibat hilangnya tumbuhan penutup tanah pada catchment area, pendangkalan sungai akibat sedimentasi, penyempitan alur sungai dan sebagainya.

\section{Kerusakan Sumberdaya Lahan}

Dalam proses produksi pertanian, kualitas sumberdaya lahan merupakan faktor produksi utama yang harus dipertimbangkan. Untuk mencapai 
pembangunan pertanian yang berkelanjutan (sustainable agriculture development) pemeliharaan dan peningkatan produktivitas lahan merupakan prasyarat mutlak yang harus dilakukan. Penurunan tingkat kesuburan tanah (land degradation) berdampak pada menurunnya jumlah dan mutu produksi pertanian, yang pada gilirannya berakibat pada penurunan tingkat pendapatan petani. Pengelolaan usahatani di lahan kering umumnya dihadapkan pada beberapa faktor pembatas, diantaranya : a). tipisnya tanah lapisan atas (top soil); b). rendahnya kandungan bahan organik; c). kemasaman tanah dan kandungan alumunium yang tinggi; d). kesuburan tanah yang rendah; e). kemiringan lahan yang curam ; dan f). terbatasnya ketersediaan air.

Kesuburan tanah adalah kemampuan tanah untuk mendukung pertumbuhan tanaman, pada kondisi iklim dan lingkungan yang sesuai. Untuk mempertahankan produksi tetap lestari, maka cara untuk memelihara atau mempertahankan kesuburan adalah dengan menciptakan penggunaan lahan dalam kondisi ekosistem alami. Beberapa kecenderungan saat ini terlihat bahwa sektor pertanian intensif secara monokultur yang menerapkan berbagai teknologi high-input pada areal yang lebih subur, telah mengakibatkan kerusakan sumberdaya yang berakibat pada makin meluasnya lahan marginal.

Bentuk - bentuk degradasi lahan antara lain: degradasi secara fisik (erosi tanah, baik oleh air ataupun angin), kimia (kemasaman tinggi dan penurunan kandungan unsur hara); dan biologi (penurunan kandungan bahan organik tanah dan aktivitas biologi tanah), salinisasi dan pencemaran tanah. Degradasi lahan adalah masalah penggunaan tanah secara inherent yang mempunyai kesuburan rendah atau mempunyai potensi relatif rendah sehingga disebut juga sebagai lahan "fragile" atau "marginal". Oleh karena itu, lahan marginal dan terdegradasi adalah lahan yang dicirikan oleh tanah dengan status hara dan kapasitas menahan air sangat rendah, dan telah mengalami kerusakan serta kehilangan fungsi hidrologi dan ekonomi (Barrow, 1991) . Perubahan lingkungan daerah tropika berkaitan erat dengan pembukaan hutan, terjadinya pergeseran lahan pertanian ke daerah tengah dan hulu dengan kemiringan lahan lebih curam dan beresiko tinggi terhadap erosi, degradasi lahan dan perluasan lahan kritis. 
Alih fungsi lahan di Lombok Timur cenderung meningkat dari tahun ke tahun. Data Dinas Pertanian dan Peternakan (2017) menunjukkan bahwa dalam selang 4 tahun mutasi lahan menurut peruntukannya dalam bentuk penurunan luas terjadi pada : sawah irigasi teknis (179 ha), sawah irigasi teknis (1.044 ha), sawah tadah hujan (331 ha), Hutan negara (9.940 ha). Mengingat trend peningkatan aktifitas pembangunan yang dibarengi dengan laju pertumbuhan penduduk yang cenderung meningkat, maka dapat dipastikan, alih fungsi lahan di Lombok Timur akan terus terjadi di masamasa yang akan datang. Sehingga tekanannya terhadap daya dukung lingkungan-pun akan terus bertambah karena pola perubahan yang cenderung negatif terhadap kelestarian lingkungan hidup.

\section{Penambangan/Penggalian}

Aktifitas penambangan/penggalian secara umum berakibat pada munculnya berbagai persoalan lingkungan hidup, karena usaha ini selalu dinilai membawa akibat negatif karena dapat menyebabkan pembuangan limbah, penggundulan hutan, penciptaan lubang - lubang besar, yang pada gilirannya berpotensi mendatangkan bahaya dan gangguan bagi lingkungan. Proses penambangan akan menghasilkan zat buangan yang berbahaya jika tidak dikelola dengan baik. Meski tidak menjadi pusat produksi tambang besar, indikasi pencemaran ditemukan di wilayah perairan Lombok Timur berdasarkan hasil studi Resources Ecological Assessment (REA) yang dilakukan oleh Fakultas Pertanian Universitas Mataram bekerjasama dengan Ditjen Perikanan Deptan pada tahun 1999, yakni ditemukan konsentrasi logam berat seperti timbal $(\mathrm{Pb})$, Krom ( $\mathrm{Cr}$ ), Kadmium (Cd) dan Tembaga (Cu) di atas ambang batas yang diperbolehkan.

Kegiatan penambangan/penggalian di Lombok Timur saat ini masih sebatas eksploitasi bahan galian golongan $\mathrm{C}$ berupa batu bangunan (batu kali, batu gunung), batu apung, tanah liat, sirtu, batu kapur serta bahan galian golongan B berupa pasir besi. Kegiatan eksploitasi telah dilakukan sejak lama dengan pola penggalian optimal terutama untuk batu bangunan, pasir, kerikil dan batu apung. Usaha penggalian dilaksanakan oleh masyarakat sekitar lokasi sebagai usaha alternatif selain pertanian. Usaha ini dilaksanakan dengan peralatan, pengetahuan dan pengalaman yang sangat terbatas. Hal ini menimbulkan berbagai permasalahan seperti terjadinya kerusakan lingkungan, gangguan 
kesehatan, keselamatan kerja dan lemahnya pengawasan, selain terdapatnya kerugian terhadap penerimaan daerah.

Dalam prakteknya, terdapat kecenderungan bahwa para pengusaha dalam usahanya untuk memperoleh laba yang memadai cenderung untuk mencari lokasi - lokasi bahan galian yang terdekat dengan daerah konsumen yang mudah cara penambangan- nya apalagi harga bahan galian golongan $\mathrm{C}$ jenis tertentu umumnya rendah, sehingga nilai jualnya sampai ke daerah konsumen sangat ditentukan oleh biaya transportasinya. Oleh sebab itu, sebagian pengusaha dalam usahanya untuk memperoleh laba yang sebanyak-banyaknya sering mengabaikan akibat-akibat negatif dalam kegiatan penggalian yang menyebabkan kerusakan lingkungan.

Adapun distribusi potensi bahan galian golongan C pada masing - masing kecamatan di Lombok Timur (2017) yakni : batu bangunan (Pringgabaya, Pringgasela, Sambelia, Terara, Selong, Sakra Timur, Sakra Barat, Sakra dan Keruak); batu apung (Pringgasela, Sikur dan Labuhan Haji); Sirtu (Aikmel, Sambelia dan Suralaga); tanah urug (Pringgabaya, Pringgasela dan Wanasaba); batu kapur (Jerowaru); tanah liat (Sikur, Terara dan
Wanasaba). Sedangkan potensi bahan galian golongan $\mathrm{B}$ berupa pasir besi terdapat di Dusun Dedalpak Pringgabaya. Sebagai dampak dari aktifitas penggalian rona lingkungan awal akan berubah, sebagai akibat pengupasan, penggalian, penimbunan, pemindahan, dan pengangkutan serta pengolahan bahan galian. Sehingga pada lahan - lahan bekas penggalian diperlukan usaha keras untuk mengembalikan kepada fungsi tata guna lahan meskipun membutuhkan waktu yang lama. Menilik data dari Dinas Pertambangan dan Industri Lombok Timur, bahwa kegiatan reklamasi (2012 s.d. 2015) baru terlaksana sekitar $15,57 \%$ $(104,42 \mathrm{Ha}$ dari sasaran areal seluas 670,74 ha). Ini berarti sekitar 566,32 ha $(84,43 \%)$ lahan penggalian batu apung, pasir dan tanah urug terlantar.

Beberapa permasalahan yang dihadapi terkait dengan kegiatan penggalian sebagaimana dirilis oleh Distamben NTB (2017), yakni : (a). Sistim pengusahaan dan nilai ekonomis yang tidak memberikan nilai tambah yang memadai; (b). Masih terjadinya usaha penambangan tanpa izin yang tidak memberi kontribusi terhadap penerimaan daerah dan pengawasan yang sulit terhadap kerusakan lingkungan, tidak menjamin K3 dan sulitnya penegakan hukum; (c) Sering 
terjadinya kecelakaan pada saat aktivitas penambangan; (e). Pemberian izin lanjutan seperti izin pemurnian, pengangkutan dan izin lainnya tidak dikaitkan dengan izin penambangan karena masih diberikan secara terpisah. Mengingat bahwa kebutuhan akan bahan galian golongan $\mathrm{C}$ pada masa yang akan datang terus meningkat, seiring dengan lajunya pembangunan di berbagai bidang, maka sudah saatnyalah dalam penentuan lokasi sumber-sumber bahan galian golongan C, perlu memperhatikan dampak lingkungan yang disebabkan oleh penambangan tersebut. Dalam pelaksanaannya pengusaha bahan galian harus mengikuti dengan benar peraturanperaturan yang berlaku baik yang menyangkut bidang pertambangan maupun lingkungan. Dengan demikian akan terlaksana cara penambangan yang lebih tertib dengan teknik penggalian yang benar dan berwawasan lingkungan

\section{Aktifitas Penambangan Bahan Galian} Golongan C

Penambangan batu apung di Pulau Lombok merupakan kegiatan eksploitasi sumberdaya alam yang telah berlangsung sejak tahun 1980. Kegiatan penambangan batu apung dilakukan pada lahan dengan tipe tanah yang berkembang dari bahan tufavulkanik hasil erupsi Gunung Rinjani.
Aktifitas penambangan menyebar di kawasan pesisir utara, bagian tengah dan kawasan pesisir Pulau Lombok termasuk didalamnya di Kabupaten Lombok Timur. Berdasarkan data Dinas Pertambangan dan Perindustrian Perdagangan Kabupaten Lombok Timur (2017), jumlah cadangan batu apung di kabupaten Lombok Timur sebanyak 140,922,652 m3 yang tersebar di beberapa kecamatan yakni di Suralaga, Labuhan Haji, Pringgasela, Masbagik, Montong Gading dan Aikmel.

Kegiatan penambangan batu apung di Kabupaten Lombok Timur secara umum dikategorikan sebagai kegiatan penambangan rakyat karena tidak menerapkan kaidah penambangan yang baik dan benar, dalam kegiatan operasinya hanya menggunakan peralatan tradisional, bahkan dilakukan secara manual. Salah satu permasalahan di daerah bekas tambang batu apung ljobalit adalah reklamasi lahan bekas tambang yang belum dapat memperoleh hasil yang optimal dan masih terbatas pada kegiatan revegetasi berupa kegiatan penanaman tanaman perkebunan (Kurniawan dan Surono, 2017).

Aktivitas penambangan batu apung di ljobalit, sebenarnya bermula dari kegiatan pengambilan batu apung yang hanyut dari 
laut oleh masyarakat sejak 1983. Saat itu, masyarakat langsung menjual hasil pengumpulan batu apung laut tersebut tanpa diproses terlebih dahulu. Pada perkembangan selanjutnya, masyarakat mengumpulkan batu apung dari rumah dan ladang serta menjualnya ke pengusaha seharga Rp. 1.000 per cikar untuk diolah lebih lanjut. Pengambilan dan pengumpulan batu apung dari ladang dimungkinkan karena areal pertanian ljobalit merupakan lahan tadah hujan sehingga aktifitas perladangan hanya berlangsung pada musim penghujan (3-4 bulan). Pada tahap awal, pemrosesan batu apung (darat) dilakukan dengan cara dihanyutkan dengan air deras agar menyamai kualitas batu apung dari laut hingga menimbulkan pemikiran penggunaan mesin molen.

Menurut penururan Zaitul Akmal (Lurah ljobalit), Penambangan batu apung di ljobalit dalam skala lebih besar dimulai sejak tahun 1987, dimana terdapat sebanyak 142 pengusaha yang melakukan penambangan di wilayah ljobalit. Seiring semakin menurunnya kandungan batu apung dan harganya yang terus menurun, maka jumlah pengusaha batu apung tersebut turun menjadi 82 pengusaha pada tahun 1996 dan sekarang hanya tinggal 12 pengusaha. Demikian pula dengan produksi batu apung yang pada awal penambangan mencapai 400.000 karung sekarang tinggal 150.000 karung. Berkembangnya penambangan batu apung di ljobalit telah memberikan kontribusi positif bagi perkembangan ekonomi khususnya kelurahan ljobalit dan sekitarnya dan masyarakat Lombok Timur pada umumnya. Hal ini terlihat dari serapan tenaga kerja yang tertampung dari kegiatan penambangan tersebut. Menurut penuturan Mamiq Nurman (mantan pengusaha batu apung), jumlah tenaga kerja (buruh) yang bekerja pada setiap pengusaha adalah tidak kurang dari 100 orang yang berarti secara keseluruhan jumlah tenaga kerja yang terserap adalah 14.000 tenaga kerja, dimana sebagian besar adalah perempuan (70 persen), dengan ongkos atau penghasilan berkisar antara 30 sampai 50 ribu perhari. Tenaga kerja (buruh) yang bekerja pada penambangan batu apung di kelurahan ljobalit tidak hanya berasal dari kelurahan Ijobalit saja, namun kebanyakn, bahkan sebahagian besar (80 persen) berasal dari luar ljobalit seperti kecamatan Suralaga dan kecamatan Aikmel.

Sementara dampak lingkungan yang timbul akibat penambangan batu apung di ljobalit dapat ditelusuri melalui kajian 
Kurniawan dan Surono (2017) tentang profil kegiatan penambangan batu apung di Kelurahan ljobalit Kecamatan Labuhan Haji Lombok Timur. Berdasarkan hasil kajian tersebut diketahui bahwa kawasan ljobalit memiliki jumlah cadangan batu apung sebesar $11.302 .500 \mathrm{~m} 3$ yang meliputi wilayah dengan luas sebaran 30.096 hektar. Kegiatan penambangan batu apung di ljobalit juga dikategorikan sebagai jenis tambang rakyat karena hanya menggunakan peralatan tradisional dan dalam skala yang kecil. Kegiatan reklamasi lahan bekas tambang sudah mencapai luas 101.42 hektare sejak tahun 2002 sampai dengan tahun 2007. Dari luasan tersebut, lahan bekas tambang batu apung yang sudah direklamasi di Kelurahan ljobalit seluas 35.25 hektar, sementara lahan yang belum direklamasi seluas 356.27 hektar.

Kegiatan penambangan batu apung ljobalit menggunakan sistem penambangan terbuka (open pit mining). Pengupasan lapisan top soil (tanah penutup) dilakukan pada sistem ini. Masalah yang kemudian terjadi adalah menurunnya tingkat kesuburan tanah menjadi lebih rendah dan kerusakan struktur tanah menyebabkan tanah mudah tererosi. Dari hasil pengujian laboratorium dapat dikatakan bahwa pada tanah bekas tambang batu apung telah terjadi penurunan tingkat kesuburan tanah. Penurunan kandungan hara makro (N, P, K), C-organik, dan nilai KTK disebabkan oleh penyingkiran lapisan tanah atas dan munculnya lapisan bawah yang bertekstur lebih kasar. Akibat pembongkaran dan pemindahan lapisan atas tersebut maka tanah bekas penambangan batu apung mengandung fraksi pasir lebih besar dari pada tanah yang tak ditambang.

Berdasarkan kriteria pengharkatan dari Pusat Penelitian Tanah Bogor 2013, sifat fisik tanah bekas penambangan batu apung memiliki agregat yang tidak mantap, porositas yang sangat tinggi dan permeabel. Pembalikan lapisan tanah akan sangat merugikan bagi pertumbuhan tanaman bekas penambangan. Degradasi struktur tanah sebagai akibat pembongkaran lapisan olah tanah akan mengakibatkan makin rentannya tanah terhadap erosi, menurunnya daya pegang tanah terhadap air (water holding capacity) dan dapat mempercepat kehilangan unsur hara di dalam tanah. Sedangkan pada lokasi yang belum ada kegiatan penambangan kualitas kesuburan tanah masih relatif baik dan mendukung pertumbuhan tanaman. 
Klasifikasi mutu air sungai termasuk dalam Kelas Dua berdasarkan peruntukan air sungai tersebut sebagai sarana rekreasi air, pembudidayaan ikan air tawar, peternakan, air untuk mengairi tanaman, dan atau peruntukan lain yang mempersyaratkan mutu air yang sama dengan kegunaan tersebut. Pemeriksaan baku mutu kualitas air sungai mengacu pada Peraturan Pemerintah Republik Indonesia Nomor 82 Tahun 2001 tentang Pengelolaan Kualitas Air dan Pengendalian Pencemaran Air. Berdasarkan hasil pemeriksaan laboratorium, sebagian besar parameter yang menentukan kualitas air sudah memenuhi baku mutu seperti yang dipersyaratkan sesuai peraturan tersebut. Sedangkan pada beberapa parameter nilainya melebihi ambang batas yang telah ditentukan seperti Total Padatan Terlarut (TDS) dan Total Padatan Tersuspensi (TSS) di lokasi tertentu.

Berdasarkan hasil kajian dari BAPPEDA Kabupaten Lombok Timur tahun 2015 sebagian air sumur warga di kelurahan ljobalit telah tercemar yang diindikasikan oleh nilai TDS dan TSS yang melebihi ambang batas. Nilai TDS yang melampaui ambang batas di lokasi sumur penduduk kemungkinan disebabkan oleh limpahan limbah rumah tangga dan bahan organik yang berasal dari kegiatan pertanian. Sementara, nilai TSS yang tinggi pada lokasi ini disebabkan oleh debu yang dihasilkan dari lalu lintas orang dan ternak, sementara tandon air tidak memiliki penutup. Senyawa organik (nitrat, nitrit) pada titik sampling sungai, sumur penduduk dan tandon air memiliki nilai yang melebihi baku mutu yang ditentukan. Sumber pencemar organik di lokasi ljobalit berasal dari limbah domestik, limbah peternakan dan pertanian. Sementara itu, kandungan bahan anorganik yang berupa logamlogam, secara umum nilainya di bawah baku mutu kualitas air, kecuali untuk logam $\mathrm{Pb}$ dan $\mathrm{Hg}$.

Lokasi kegiatan penambangan batu apung berada di dekat pantai yang berpasir, memiliki kelembaban rendah dan suhu tinggi. Akibatnya tumbuhan yang mampu beradaptasi dengan baik pada kondisi tersebut adalah jenis tanaman pendek. Jenis tanaman pendek seperti rumputrumputan mendominasi di lokasi penambangan batu apung ljobalit. Sedangkan pada lahan bekas tambang yang telah direklamasi terdapat berbagai jenis tanaman antara lain mangga (Mangifera indica), pohon jati (Tectona grandis), kelapa (Cocos nucifera), jambu monyet (Anacardium occidentale), pisang 
(Musa sp.) dan singkong (Manihot utilisima). Pemilihan tanaman tersebut berdasarkan sifat tanaman yang sesuai dengan kondisi tanah di daerah tersebut. Sementara, keberadaan satwa liar tidak ditemukan pada lokasi kegiatan tambang karena sudah menjadi area terbuka dan tidak cocok untuk kehidupan satwa liar. Saat ini, persediaan batu apung dirasakan sudah semakin berkurang apalagi sejak penggunaan mesin yang mampu mengangkat batu apung hingga kedalaman penggalian mencapai 20 meter dibandingkan secara manual yang hanya mencapai 2 meter. Usaha penggalian batu apung sudah tidak bisa diandalkan lagi sebagai sumber utama penghidupan keluarga karena pendapatan dari aktifitas ini makin menurun dari tahun ke tahun sehingga penduduk mulai banyak berangkat ke Luar Negeri sebagai TKI. Sementara, areal bekas penggalian batu apung tidak bisa diharapkan sebagai lahan bercocok tanam karena memerlukan waktu lama untuk mengembalikan unsur-unsur hara tanah.

\section{KESIMPULAN DAN SARAN}

\section{Kesimpulan}

Beberapa kesimpulan penting dari kajian ini berdasarkan temuan di lapangan dan hasil dari pembasan di atas adalah sebagai berikut :
1. Penambangan batu apung muncul sebagai implikasi dari tingginya pertumbuhan penduduk yang tidak diikuti dengan peningkatan kualitas sumberdaya manusia (SDM) dan penyediaan lapangan pekerjaan yang cukup. Kondisi ini memicu tekanan terhadap lingkungan sekitar untuk dijadikan sumber penghidupan yang paling memungkinkan karena tidak membutuhkan keterampilan khusus.

2. Kegiatan penambangan batu apung di Kelurahan Ijobalit Kecamatan Labuhan Haji Kabupaten Lombok Timur secara umum tergolong penambangan rakyat dimana dalam kegiatan operasinya hanya menggunakan peralatan tradisional, bahkan dilakukan secara manual.

3. Kegiatan penambangan batu apung ljobalit menggunakan sistem penambangan terbuka (open pit mining) dengan mengupas lapisan top soil (tanah penutup) yang berdampak pada penurunan tingkat kesuburan dan kerusakan struktur tanah sehingga menyebabkan tanah mudah mengalami erosi. 


\section{Saran}

Penambangan batu apung muncul sebagai implikasi dari tingginya pertumbuhan penduduk yang tidak diikuti dengan peningkatan kualitas sumberdaya manusia (SDM) dan penyediaan lapangan pekerjaan yang cukup. Kondisi ini memicu tekanan terhadap lingkungan sekitar untuk dijadikan sumber penghidupan yang paling memungkinkan karena tidak membutuhkan keterampilan khusus. Kegiatan penambangan batu apung ljobalit menggunakan sistem penambangan terbuka (open pit mining) dengan mengupas lapisan top soil (tanah penutup) yang berdampak pada penurunan tingkat kesuburan dan kerusakan struktur tanah sehingga menyebabkan tanah mudah mengalami erosi.

Berdasarkan temuan di lapangan dan hasil pembahasan di atas, beberapa hal perlu dilakukan sebagai berikut :

1. Untuk mencegah dan mengantisipasi persoalan yang timbul akibat dinamika penduduk yang berdampak terhadap kerusakan lingkungan, pemerintah harus memastikan penambangan dilakukan dengan kaidah dan prosedur yang benar, disertai dengan pengwasan danpenegakan hukum bila terjadi penyimpangan.

2. Untuk meminimalisisr dampak negative yang timbul akibat penambangan batu apung, selain control pemerintah daerah/ dinas terkait, perangkat desa dan peran komonitas masyarakat sebagai lembaga control perlu diberdayakan.

3. Untuk menjamin kepastian hukum dalam pengelolaan penambangan, maka dipandang perlu untuk membuat Peraturan Daerah (PERDA) tentang pengelolaan pertambangan husunya pertambangan golongan $\mathrm{C}$.

4. Seiring dengan persediaan batu apung yang semakin menurun, penambangan batu apung tidak bisa lagi diandalkan sebagai sumber utama penghidupan keluarga karena pendapatan dari aktifitas ini makin menurun. Pemerintah daerah perlu mempercepat proses reklamasi tanah bekas tambang batu apung agar dapat dimanfaatkan sebagai lahan pertanian sehingga terbuka lapangan kerja baru bagi para penambang batu apung. Disamping itu perlu dipikirkan 
I96 Jalaluddin,Irwan Suriadi/Dinamika Kependudukan dan Dampaknya...

$\begin{array}{ll}\text { bentuk- bentuk pemberdayaan } & \text { wirausaha dan bentuk } \\ \text { bagi masyarak eks tambang } & \text { keterampilan lainnya. } \\ \text { misalnya memberikan pelatihan } & \text {. }\end{array}$

\section{DAFTAR PUSTAKA}

BKKBN, 2012. Tekanan Penduduk dan Dampak Terhadap Lingkungan. Makalah. Seminar Peningkatan Kualitas Lingkungan Keluarga, Jakarta.

BKKBN, 2017. Dinamika Kependudukan dan Perubahan Iklim. Direktorat Analisis Dampak Kependudukan.

BKKBN, 2017. Profil Kependudukan dan Pembangunan di Indonesia Tahun 2017. Jakarta.

Hardiani dan Junaidi. 2011. Analisis Kuantitas dan Kualitas Penduduk sebagai Modal Dasar dan Orientasi Pembangunan di Provinsi Jambi. Pusat Studi Kependudukan Universitas Jambi.

Kurniawan, A.R dan W. Surono, 2017. Model Reklamasi Tambang Rakyat Berwawasan Lingkungan : Tinjauan Atas Reklamasi Lahan Bekas Tambang Batu Apung ljobalit, Kabupaten Lombok Timur, Propinsi Nusa Tenggara Barat. Jurnal Teknologi Mineral dan Batubara Volume 9, Nomor 3, September 2017 : 165-174.

Lucas.D. et.al. 1990. Pengantar Kependudukan. Yogyakarta. Gadjah Mada University Press.

Odum, 1971, Fundamentals of Ecology. Third edition. WB. Saunders Company.

Soerjani M, Ahmad R., Munir R., 1987. Sumberdaya Alam dan Kependudukan dalam Pembangunan. Penerbit Universitas Indonesia

Utina, R dan D.W.K. Baderan., 2013. Dampak Kepadatan Penduduk Terhadap Kondisi Biofisik Lingkungan Hidup di Provinsi Gorontalo. Laporan Akhir.

Yakin, A., 1997. Ekonomi Sumberdaya dan Lingkungan. Penerbit. CV. Akademika Presindo. 